LAPORAN KASUS

\title{
Penanganan Perioperatif Pasien Dengan TOF dan Kardiomiopati Dilatatif Disertai Multiple Thrombus di Semua Ruang Jantung
}

\section{Perioperative Management Tetrallogy of Fallot in an pediatric with Cardiomyopathy and multiple thrombus Formation}

Fajar Perdhana *, Prieta Adriane *

*Rumah Sakit Pusat Jantung Nasional Harapan Kita, Jakarta

\section{ABSTRACT}

Tetralogy of Fallot defined as a condition of congenital heart defect which is classically understood to involve comprises right ventricular (RV) outflow tract obstruction (RVOTO) (infundibular stenosis), Ventricular septal defect (VSD), aorta dextroposition, and RV Hypertrophy. This condition was worsen by cardiomyopathy leading to heart failure and multiple thrombus formation in all chamber of the heart. Perioperative challenges include "tet spell" at any time during the pre CPB period, which is can cause by anesthetic induction and manipulation of the heart and great vessels by the sugeon, and decrease of the heart fuction caused by cardiomyopathy can lead to heart failure. Postoperatively, patients may encounter low cardiac output syndrome. A 2 years and 10 months child, diagnose as TOF with dilatative cardiomyopathy and multiple thrombus formation, undergoing total correction procedure. She hospitalized with serious complications such as heart failure and severe decrease of left and right ventricle fuction. Patient were monitored with standard electrocardiogram, pulse oximetry and non invasive blood pressure. The patient was performed anesthesia with inhalation induction with sevoflurane, then performed invasive blood pressure in left radial artery and central venous catheter $(C V C)$ in right jugular vein The operation was performed to evacuated all thrombus, VSD closure with goretex patch and infundibulum resection and then performed pericardial patch to dilate Right Ventricel Outflow Tract (RVOT). Patient had low cardiac ouput syndrome in post operative periods, were treated for 21 days in ICU, and tracheostomy was performed on day 9 of care. The patient was successfully weaned from the ventilator at day 13. A total correction procedure for TOF patient with dilatative cardiomyopathy is a challenge for anesthesiologists. Good preoperative preparation, durante operation management and careful monitoring on postoperative care produce good results.

Keywords: Tetrallofy of Fallot, Dilatative Cardiomyopathy, thrombus, low cardiac output syndrome

\begin{abstract}
ABSTRAK
Tetrallogy of Fallot (TOF) didefinisikan sebagai kondisi penyakit jantung kongenital yang ditandai dengan adanya obstruksi right ventricle outflow tract (RVOTO) baik
\end{abstract}

Volume IX, Nomor 1, Tahun 2017

Terakreditasi DIKTI dengan masa berlaku 3 Juli 2014 - 2 Juli 2019

Dasar SK Menteri Pendidikan dan Kebudayaan RI Nomor 212/P/2014 
stenosis pada supravalvar, valvar dan subvalvar, adanya ventricle septal defect (VSD), dextroposisi dari aorta dan hipertrofi ventrikel kanan. Kondisi ini diperberat dengan kardiomiopati dilatatif yang menyebabkan pasien jatuh pada keadaan gagal jantung dan pembentukan trombus multipel di semua ruang jantung. Tantangan perioperatif adalah terjadinya tet spell pada periode pre CardioPulmonary By pass (CPB), dan depresi kontraktilitas dapat menyebabkan gagal jantung. Pasca operasi beresiko tinggi untuk terjadi low cardiac output syndrome. Anak usia 2 tahun 10 bulan dengan diagnosis TOF dan kardiomiopati dilatatif disertai pembentukan trombus multipel yang menjalani prosedur total koreksi, dengan penyulit penyerta gagal jantung yang membaik dengan terapi medikamentosa, fungsi ventrikel kiri dan ventrikel kanan yang turun. Pasien dipasang monitoring standar EKG, SpO2, dan NIBP, kemudian dilakukan induksi inhalasi dengan sevofluran, selanjutnya dilakukan pemasangan invasif blood pressure pada arteri radialis kiri dan pemasangan kateter vena sentral (CVC) pada vena jugularis kanan. Dilakukan tindakan evakuasi trombus, penutupan VSD dengan goretex patch dan reseksi infundibulum kemudian dilakukan pericardial patch untuk melebarkan Right Ventricel Outflow Tract (RVOT). Pasca operasi pasien mengalami low cardiac ouput syndrome, dirawat selama 21 hari di ICU, dan dilakukan trakeostomi pada perawatan hari ke-9. Pasien berhasil disapih dari ventilator pada perawatan hari ke-13 dan pindah dari ICU ke ruang perawatan pada hari ke-21. Prosedur total koreksi pada pasien TOF dengan disertai kardiomiopati dilatatif merupakan tantangan tersendiri bagi dokter ahli anestesi. Persiapan pre-operasi yang baik, manajemen durante operasi dan monitoring yang seksama serta perawatan pasca operasi yang berkesinambungan menghasilkan hasil yang baik.

Kata kunci : TOF, total koreksi, kardiomiopati dilatatif, low cardiac output syndrome, trombus

\section{PENDAHULUAN}

Tetrallogy of Fallot (TOF) dijumpai pada $10 \%$ kasus penyakit jantung kongenital, TOF adalah bentuk paling umum dari penyakit jantung sianotik. Dokter Prancis Etienne Fallot, 1888, pertama kali mempublikasikan deskripsi kelainan klinik dan anatomik secara komprehensif, berdasarkan sejumlah penelitian postmortem. TOF ditandai dengan adanya Ventricular Septal Defect (VSD), Overriding aorta, right ventricular hypertrophy, stenosis pulmonal (infundibular atau subvalvular, valvular, supravalvular atau kombinasi). ${ }^{1,2,3}$

Lillehei pertama kali berhasil melakukan prosedur total koreksi pada TOFtahun 1954. Prosedurtotal koreksi ditujukan untuk menghilangkan obstruksi dengan melakukan reseksi dinding yang hipertrofi, dan melebarkan RVOT dengan pericardial patch. ${ }^{4}$ 


\section{KASUS}

Anak perempuan usia 2 tahun 10 bulan dengan berat badan $12 \mathrm{Kg}$, datang dengan keluhan sesak, batuk dan pilek lama, bengkak seluruh tubuh, demam 1 minggu, disertai sianosis. Lahir cukup bulan, sianosis $(+)$. Hasil echocardiografi menunjukkan RA, RV dilatasi; TR ringan, PS sedang; tampak vegetasi di katup pulmonal UK 0.6x0.04; dan septum ventrikel VSD defek IVS $1.17 \mathrm{~L}$ to $R$ shunt. Kesimpulan hasil echocardiografi TOF + vegetasi katup pulmonal + PS sedang+ TR ringan. Disarankan untuk dilakukan operasi BT shunt.

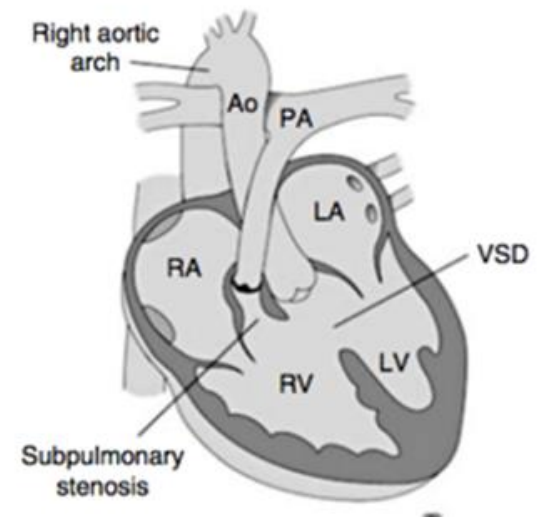

Gambar 1. Tetrallogy of Fallot

Pemeriksaan fisik didapatkan jalan nafas bebas, frekuensi nafas $28 \mathrm{kali} /$ menit, tidak ada ronkhi dan wheezing, $\mathrm{SpO} 265 \%$, perfusi hangat sianotik dengan tekanan darah 90/50 $\mathrm{mmHg}$, Nadi 128 kali/menit. Pasien sadar tampak lemah. didapatkan abdomen sedikit distensi dan ada asites. Ekstremitas dijumpai pitting edema, clubbing finger, dan sianotik. Pemeriksaan foto ronsen thorak didapatkan jantung tidak dapat dievaluasi, efusi pleura kiri masif.
Konfirmasi dengan USG thorak didapatkan efusi pleura kiri. Dilakukan echocardiografi ulang, didapatkan hasil multiple thrombus LV 1,89 X 2,05 cm, thrombus di RA $2,75 \times 3,4 \mathrm{~cm}$, MPA $0,89 \times 1,01 \mathrm{~cm}$, di RVOT $0,7 \times 0,7$ $\mathrm{cm}$.

Hasil pemeriksaan MSCT Cardiac: kardiomegali terutama pembesaran dari RA dan LV disertai thrombus pada LV ukuran terbesar $3.8 \times 2 \times 1.2 \mathrm{~cm}$, pada PA ukuran $4.3 \times 2.6 \times 2.9 \mathrm{~cm}$, dan multiple pada RV ukuran terbesar $0.3 \times 0.4$ x $0.5 \mathrm{~cm}$; Brachiocephalic vein tampak prominen dengan thrombus yang luas pada dindingnya; VSD sepanjang 1.74 cm lokasi dekat dengan aortic knob; efusi perikardium minimal dan efusi

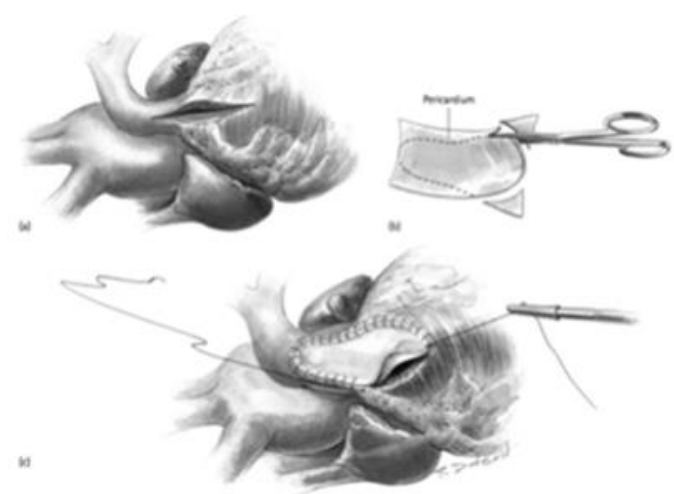

Gambar 2. Prosedur Total Koreksi

pleura kiri; dan hepatomegali.

Pasien kemudian didiagnosis dengan TOF + Endokarditis + Dilated Cardiomyophaty + Multiple Trombus + Heart failure. Hasil laboratorium dalam batas normal, dengan analisa gas darah sedikit asidosis metabolik dengan pH 7,33.

Dilakukan induksi inhalasi sevofluran, dengan ko induksi Midazolam $2 \mathrm{mg}$ IV, Fentanyl $30 \mathrm{Mcg}$ IV, Vecuronium 2 mg IV, dilakukan intubasi sleep apneu ETT 
4,5 , cuff $(+)$, batas bibir $12 \mathrm{~cm}$. Maintenance dengan Sevoflurane dan oksigen. Selama operasi diberikan suplemen Fentanyl dan vecuronium.Alat monitoring invasif dipasang arteri line pada arteri radialis sinistra, dan kateter vena sentral pada V. Jugularis Interna dextra. Dilakukan transesofageal ekokardiografi sebelum dan setelah koreksi. Tindakan operasi yang dilakukan adalah evakuasi thrombus, penutupan VSD dengan goretex patch dan reseksi infundibulum kemudian dilakukan pericardial patch untuk melebarkan RVOT. Pasca operasi pasien disedasi dengan kontrol penuh ventilasi. Hemodinamik ditopang dengan adrenalin dan milrinon. Dilakukan trakeostomi pada hari rawat ke9. Pasien dapat diekstubasi pada hari rawat ke-13 dan pindah ke ruang perawatan biasa pada hari rawat ke-19.

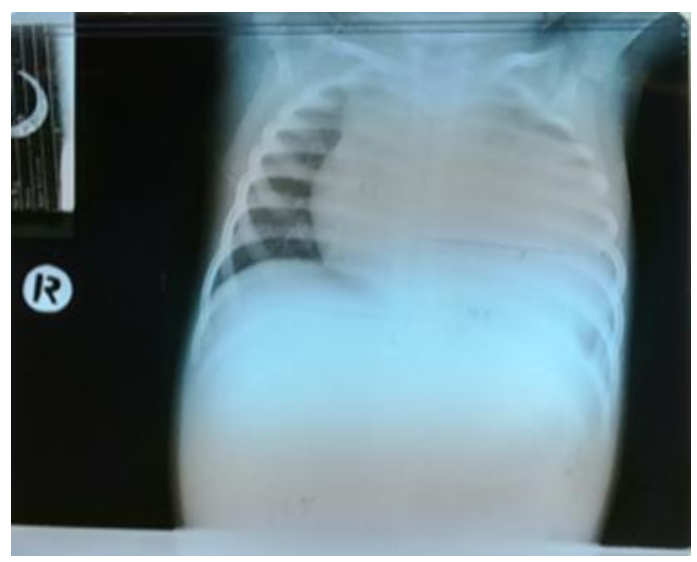

Gambar 3. Foto ronsen thorak sebelum operasi

\section{Manajemen Gagal Jantung pada Anak}

Pada kasus ini pasien datang dalam kondisi gagal jantung, gagal jantung pada anak-anak banyak disebabkan oleh penyakit jantung kongenital dan kardiomiopati. Hal ini sangat berbeda dengan gagal jantung yang terjadi pada pasien dewasa yang sering disebabkan oleh penyakit jantung koroner dan hipertensi. Manajemen gagal jantung pada anak-anak sebagian besar berdasarkan pengalaman klinis dan aplikasi dari data pada terapi gagal jantung pada dewasa. Pre operasi pasien ini mendapat terapi diuretik, ace inhibitor, beta bloker dan dobutamin. Pasien ini mengalami gagal jantung yang disebabkan oleh kardiomiopati dilatatif dan kondisinya diperberat dengan adanya kelainan jantung kongenital TOF. Manajemen gagal jantung pada pasien ini dengan restriksi cairan dan medika mentosa.

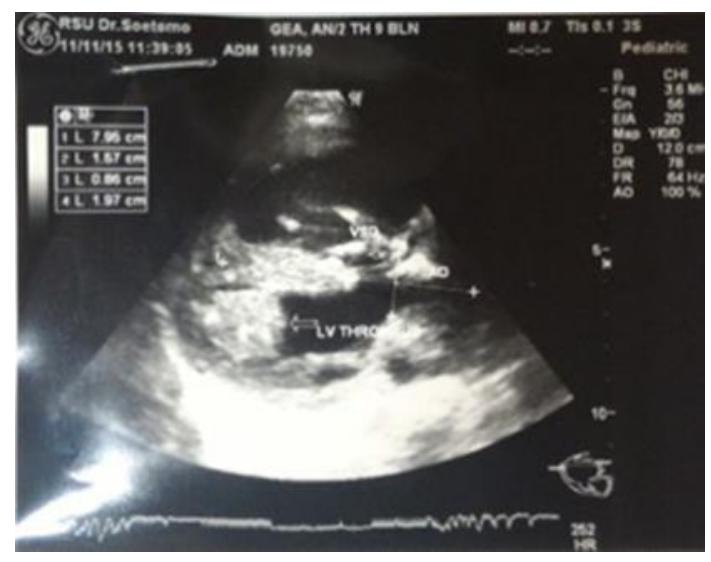

Gambar 4. Echocardiografi sebelum operasi

Terapi medika mentosa yang diberikan antara lain diuretik, memiliki keuntungan pada gagal jantung melalui peningkatan kehilangan cairan, peningkatan kehilangan sodium. Digunakan luas pada gagal jantung dewasa dan anak-anak, mengurangi gejala dengan cepat akibat volume overload. Pilihan diuretik adalah loop diuretik karena efeknya yang kuat, namun memiliki 
potesi efek yang tidak diinginkan terhadap kadar magnesium dan calcium intra dan extra seluler dan defisiensi thiamin.Cochrane systematic review menyimpulkan diuretik menurunkan resiko kematian dan memburuknya gagal jantung. ${ }^{5}$

Terapi yang lain menggunakan $A C E$ inhibitor yang berfungsi menurunkan efek yang dihasilkan dari aktivasi sistem RAA yang sering terjadi pada keadaan gagal jantung. Keuntungan efek $A C E$ inhibitor pada gagal jantung antara lain menurunkan vasokonstriksi, potensiasi aktivitas system saraf simpatis, dan menurunkan pelepasan aldosterone (sehingga menurunkan retensi air dan sodium, fibrosis myocardial, hambatan pelepasan NO, dan kerusakan bradikinin vasodilator). Ketiga proses tersebut dimediasi oleh Angiotensin II.

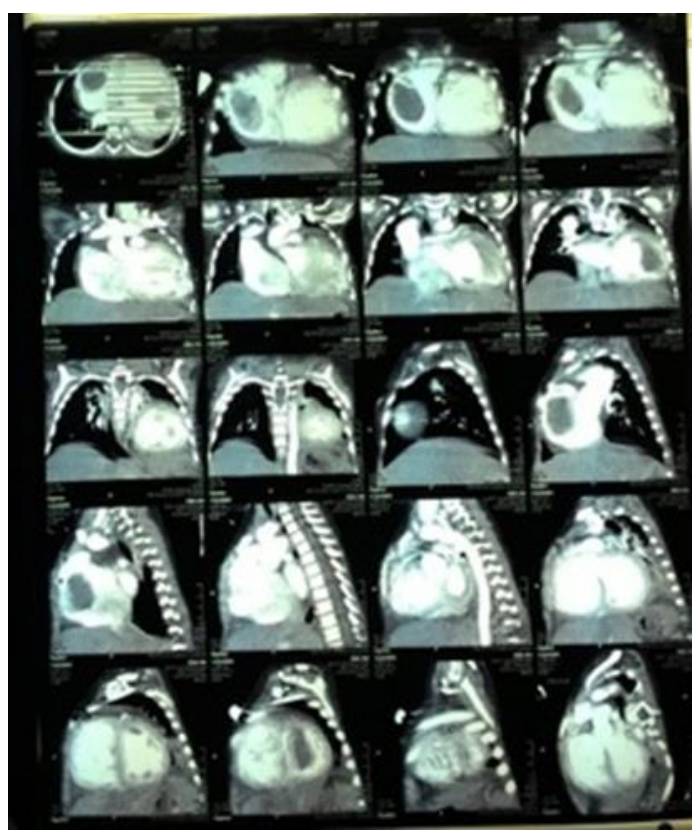

Gambar 5.Gambaran MSCT jantung sebelum operasi
Beta blockers melawan aktivasi sistem saraf simpatis yang sering muncul pada gagal jantung. Keuntungan beta blocker antara lain menurunkan denyut jantung, meningkatkan keseimbangan oksigen supply dan demand, menurunkan myocardial apotosis dan fibrosis, efek anti aritmia, dan bersinergi dengan $A C E$ inhibitor. Terapi yang lain adalah dobutamin, yang digunakan pada gagal jantung yang berat, dimana terjadi penurunan cardiac output dan penurunan tekanan darah. Dobutamin menstimulasi kontraktilitas jantung.

\section{Koagulopati pada anak dengan pen- yakit jantung kongenital (PJK)}

Anak dengan penyakit jantung sering memiliki gangguan dalam keseimbangan hemostasis, yang dapat mengakibatkan perdarahan, trombosis, atau keduanya.Penyakit jantung kongenital sianotik dilaporkan memiliki kecenderungan lebih mengalami system hemostatic abnormal dibandingkan penyakit jantung kongenital asianotik dan penyakit jantung didapat (penyakit Kawasaki, kardiomiopati).

Studi pada anak-anak dengan PJK menunjukkan adanya abnormalitas protein-protein yang tertera dibawah dan abnormalitas fungsi hemostatik, yang dapat menimbulkan resiko perdarahan dan atau thrombosis. ${ }^{6}$ Protein koagulasi faktor II, V, VII, VIII, IX, X, dan fibrinogen menurun; faktor VIII meningkat. Inhibitor koagulasi protein $\mathrm{C}, \mathrm{S}$ dan anti thrombin menurun. Protein fibrinolitik: plasminogen menurun. Protrombotik polimorfisme genetik mengidentifikasi adanya : Faktor V Leiden, pro- 
trombin gen 20120, plasminogen G4 / G4, metilen tetrahidrofolat reduktase 677.

Kelainan fungsi hemostatik meliputi : peningkatan koagulasi, peningkatan atau penurunan fibrinolisis,peningkatan atau penurunan jumlah dan fungsi trombosit, dan faktor lain berupa kerusakan endotel vaskular yang dipicu pemsangan kateter vena sentral, CPB dan ECMO.

\section{Tatalaksana Anestesi pada Pasien TOF}

Pada kondisi yang cukup optimal, pasien ini diputuskan untuk dilakukan operasi definitif, yaitu total koreksi. Pertimbangan dilakukan total koreksi karena pasien ini akan dilakukan open chamber untuk evakuasi thrombus, dari hasil kateterisasi tidak didapatkan abnormalitas dari arteri koroner, dari hasil evaluasi di meja operasi didapatkan PA konfluens ukuran Anulus PA sesuai dengan full size dan tidak ada stenosis di RPA maupun LPA.

Induksi anesthesia pada pasien ini dilakukan dengan memperhatikan hal-hal sebagai berikut : ${ }^{1,2,3}$

1. Menjaga frekuensi jantung, kontraktilitas, dan preload untuk menjaga cardiac output. Euvolemia sangat penting untuk menjaga obstruksi RVOT yang dinamis yang dapat disebabkan hipovolemia sehingga frekuensi jantung dan kontraktilitas meningkat.

2. Menghindari rasio PVR:SVR. Semakin rendah derajat lesi obstruksi
RVOTsemakin penting menjaga rasio PVR:SVR. Peningkatan PVR relatif terhadap SVR, dan penurunan SVR relatif terhadap PVR, dapat meningkatkan shunt R_L, menurunkan aluran darah pulmonal, dan menyebabkan atau memperberat derajat sianosis.

3. Manajemen ventilator untuk menurukan PVR.

4. Menjaga atau meningkatkan SVR. Sangat penting pada keadaan obstruksi RVOT yang berat.

5. Menangani secara agresif episode hipersianosis

6. Menjaga kontraktilitas. Penurunan kontraktilitas pada keadaan obstruksi RVOT yang berat dapat menyebabkan RV afterload mismatch dan menurunkan aliran pulmonal secara dramatis. Kecuali pada pasien dengan obstruksi RVOT pada infundibulum, penurunan kontraktilitas dapat menurunkan derajat obstruksi.

Induksi intravena banyak dilakukan namun kebanyakan bayi dan anak-anak dapat mentoleransi induksi inhalasi baik dengan sevofluran atau halothane. Halothane mungkin lebih baik jika dibandingkan dengan sevofluran dalam menurunkan komponen obstruksi RVOT yang dinamis, karena halothane memiliki efek inotropik negatif yang potent. Hipotensi sistemik harus dihindari atau segera diatasi, karena dapat menyebabkan atau meningkatkan R-L shunt pada keadaan obstruksi RVOT yang berat. 
Manajemen Hipersianotik atau "Tet Spell'

Terjadinya episode hipoksia pada pasien TOF dapat mengancam jiwa. Spell lebih sering terjadi pada pasien sianosis dengan frekuensi puncak spell usia antara 2 - 3 bulan. Timbulnya spell biasanya memerlukan intervensi bedah segera. Etiologi spell tidak sepenuhnya dipahami, tetapi spasme infundibular mungkin berperan. ${ }^{4}$

Hiperpnea paroksismal adalah gejala awal.Ada peningkatan laju dan kedalaman respirasi, yang mengarah ke peningkatan sianosis dan potensi sinkop, kejang atau kematian. Selama spell, bayi akan tampak pucat dan lemas akibat aliran darah jantung yang berkurang. Hiperpnea meningkatkan konsumsi oksigen melalui peningkatan kerja pernapasan. Hipoksia menginduksi penurunan systemic vascular resistance (SVR), yang selanjutnya meningkatkan R-L shunt. Hiperpnea juga menurunkan tekanan intratoracic dan mengarah ke peningkatan aliran balik vena sistemik. Obstruksi infundibular akan meningkatkan preload RV dan peningkatan R-L shunt.

Terapi pada spell meliputi:3,4

- Pemberian oksigen 100\%.

- Kompresi arteri femoralis atau menempatkan pasien dalam kneechest position meningkatkan SVR dan mengurangi R-L shunt. Kompresi manual dari aorta abdominal sangat efektif untuk pasien dalam pembiusan. Setelah dada terbuka, ahli bedah dapat mengkompresi aorta asending untuk meningkatkan impedansi ejeksi LV.

- Pemberian morfin sulfat (0.05$0.10 \mathrm{mg} / \mathrm{kg}$ ), dengan melakukan sedasi pasien dapat menurunkan efek hiperpnea.

- Pemberian cairan kristaloid 1530mL / kg. Meningkatkan preload akan meningkatkan ukuran jantung, yang dapat meningkatkan diameter RVOT.

- Pemberian sodium bicarbonate untuk mengatasi asidosis metabolik berat yang terjadi selama spell. Koreksi asidosis metabolik akan menormalkan SVR dan mengurangi hiperpnea. Pemberian bikarbonat (1-2 mEq / kg) tanpa adanya analisis gas darah diperbolehkan selama spell.

- Phenylephrine dalam dosis yang relatif besar $(5-10 \mu \mathrm{g} / \mathrm{kg}$ IV bolus atau 2-5 $\mu \mathrm{g} / \mathrm{kg} / \mathrm{min}$ ) meningkatkan SVR dan mengurangi R-L shunt. Obstruksi RVOT berat, pemberian phenylephrine menginduksi meningkatkan PVR memberikan efek yang sedikit atau tidak berpengaruh dalam meningkatkan ketahanan RV outflow.

- Agonis beta-adrenergic merupakan kontraindikasi absolut. Peningkatan kontraktilitas akan lebih mempersempit infundibulum stenosis.

- Pemberian propranolol $(0,1 \mathrm{mg} / \mathrm{kg})$ atau esmolol $(0.5 \mathrm{mg} / \mathrm{kg}$ diikuti dengan drip 50-300 $\mathrm{mg} / \mathrm{kg} / \mathrm{min}$ ) dapat mengurangi spasme infundibular dengan menekan kontraktilitas. Selain itu, memperlambat denyut jantung memungkinkan untuk meningkatkan pengisian diastolik 
(peningkatan preload), peningkatan ukuran jantung, dan peningkatan diameter RVOT.

- Resusitasi Extra corporeal membrane oxygenation (ECMO) pada episode refraktori jika intervensi operasi segera tidak memungkinkan.

\section{Manajemen pasca $C P B^{1,2,3,4}$}

1. Menjaga denyut jantung tetap sinus dengan frekuensi jantung yang sesuai dengan usia. Cardiac output lebih tergantung pang frekuensi jantung pasca CPB. Kadang diperlukan pemasangan atrial pacing jika terdapat junctional ectopic tachycardia (JET)

2. Menurunkan PVR melalui intervensi ventilator.

3. Support inotropik untuk RV kadang diperlukan. Penggunaan dobutamin (5-10 $\mathrm{mcg} / \mathrm{kgbb} / \mathrm{min})$ atau dopamine (5-10 $\mathrm{mcg} / \mathrm{kgbb} / \mathrm{min})$ dapat menjadi pilihan karena memiliki efek inotropic yang potenttanpa meningkatkan PVR. Milrinone (0,5-1 mch/ $\mathrm{kgbb} / \mathrm{min}$ ) dapat digunakan karena efek inotropic dan lusitropiknya serta efeknya pada PVR.

Setelah total koreksi, ada beberapa faktor yang dapat mempengaruhi fungsi sistolik dan diastolic dari ventrikel kanan, diantaranya : $:^{3,4}$

a. Prosedur ventrikulotomi kanan dan pemasangan patch pada RVOT dapat menyebabkan dyskinesia pada dinding bebas ventrikel kanan.

b. Proteksi myocardial pada ventrikel kanan saat cross clamping aorta sulit karena adanya hipertrofi. c. Pelebaran RVOT dengan transanular patch dapat menyebabkan regurgitasi pulmonal, sehingga menambah beban volume pada RV

d. Adanya residual obstruksi pada RVOT menambah beban pada RV

e. VSD residual menambah beban volume pada RV

\section{Low Cardiac Ouput Syndrome (LCOS)}

Operasi jantung konvensional yang melibatkan Cardiac arrest dan CPB berhubungan dengan disfungsi miokard pasca operasi danLCOS.Faktor intraoperatif diduga terkait dengan kerusakan miokard :1) jenis solusi yang digunakan untuk priming $\mathrm{CPB}, 2$ ) aritmia persisten, terutama fibrilasi ventrikel (VF) 3) proteksi miokard yang tidak adekuat 4) distensi ventrikel, 5) emboli arteri koroner, 6) penggunaan katekolamin, 7) lama aortic cross clamping, 8) prosedur bedah kompleks (misalnya, ventrikulostomi), 9) reperfusi diikuti iskemia, 10) waktu CPB, dan 11) respon inflamasi sistemik. Selain itu, beberapa factor spesifik seperti miokardium neonatus, hipertrofi ventrikel, sianosis berat dan gagal jantung yang sudah ada sebelumnya, mempengaruhi kerentanan miokardium dan kecenderungan untuk LCOS. ${ }^{7}$

Pada tingkat seluler dan molekuler, beberapa mekanisme terkait dengan terjadinya disfungsi miokard dan LCOS pada pasien anak yang menjalani operasi jantung. Salah satu diantaranya ischemia reperfusion injury dengan gangguan homeostasis kalsium dan ke- 
rusakan mitokondrial, secara konsisten dilaporkan memegang peranan besar terjadinya disfungsi jantung pasca operasi. $^{7}$

Pada kasus ini pasca CPB kontraktilitas LV dan RV tidak terlalu baik dengan Tapse 1,0 dan LVEF 35\%, dengan pertimbangan pasien ini dengan gagal jantung maka sudah dalam keadaan beta reseptor down regulation dan pasien sudah diprediksi resiko timggi jatuh pada keadaan low cardiac ouput syndrome,oleh karena itu pemilihan inotropic adalah inotropic kuat dengan adrenalin dan inotropic non beta reseptor yaitu milrinon. Pada guideline penggunaan milrinon, indikasi milrinon diantaranya gagal jantung kongestif, fase low cardiac output pasca bedah jantung, pasien yang refrakter dengan inotropic beta reseptor, sebagai profilaksis pasien yang resiko tinggi terjadi low cardiac output syndrome pasca bedah jantung seperti Arterial switch dan TOF.

\section{DAFTAR PUSTAKA}

1. Jonas, Richard A. 2004. Comprehensive Surgical Managementof Congenital Heart Disease. Hodder Arnold. p 279283

2. Andropaulus, Dean B. 2010. Anesthesia for Congenital Heart Disease. WilleyBlackwell. p 419-430

3. Dinardo, James A. 2008. Anesthesia for Cardiac Surgery. Blackwell Publishing. p 167

4. Hensley, Frederick A. Cardiac Anesthesia. $5^{\text {th }}$ Ed. Lippincot William \& Wilkins. P 1739

5. Beggs, Sean. 2008. Cardiac Failure in Children. Pediatric Department, Royal hobart Hospital and University of tasmania

6. Giglia, Therese M, et al. 2013. Prevention and Treatment of Thrombosis in Pediatric and Congenital Heart disease. Circulation.2013;128:2611-2703

7. Bautista, Victor.2016. Cellular and Molecular Mechanisms of Low Cardiac output Syndrome after Pediatric Cardiac Surgery. Current Vascular Pharmacology, 2016, Vol. 14, No. 1 